\title{
Risk factors of vitamin D deficiency in children with epilepsy taking anticonvulsants at initial and during follow-up
}

Seung Ho Lee, MD,

Jeesuk Yu, MD, PhD

Department of Pediatrics, Dankook University Hospital, Cheonan, Korea
Purpose: Vitamin D status was evaluated in children with epilepsy taking anticonvulsants to determine the prevalence and risk factors of vitamin D deficiency.

Methods: This study was designed as both a cross-sectional and a retrospective cohort study. A sum of 198 children who were diagnosed with epilepsy at the Department of Pediatrics in Dankook University Hospital was included. Their serum vitamin D levels were reviewed based on clinical information, and analyzed using IBM SPSS ver. 20.0.

Results: One hundred twenty-four children (62.6\%) had vitamin D deficiency. Two risk factors were associated: winter to spring season (odds ratio [OR], 3.71; 95\% confidence interval $[\mathrm{Cl}], 1.835-7.492)$ and age more than 12 years (OR, 3.22; 95\% $\mathrm{Cl}, 1.377-7.542)$. Out of the 57 patients who were not vitamin $\mathrm{D}$ deficient at the time of initial assay, 47 patients (82.5\%) became vitamin $D$ deficient during followup. The change of serum 25-hydroxy vitamin D3 (25(OH)D) levels during follow up showed a weak negative correlation with the duration of medication $(r=-0.283$, $P=0.033$ ). Medication duration was longer and brain magnetic resonance imaging (MRI) abnormality, abnormal underlying conditions, and nonambulatory status were more frequently present in twenty-five patients $(44 \%)$ who showed a decline of more than $15 \mathrm{ng} / \mathrm{mL}$ during follow-up $(P<0.05)$.

Conclusion: Vitamin D deficiency is common in children with epilepsy taking anticonvulsants, especially in adolescents more than 12 years of age. This study emphasizes the regular monitoring of vitamin D level, especially in the presence of longer duration of medication, brain MRI abnormality, abnormal underlying conditions, and nonambulatory status.

Keywords: Vitamin D deficiency, Child, Epilepsy, Anticonvulsants

\section{Introduction}

Vitamin D deficiency is an emerging medical issue due to its high prevalence and important role in human health. Vitamin D plays a critical role in calcium and bone metabolism. Vitamin D plays multiple roles including increasing the absorption of calcium and phosphorus in the intestine and inhibiting the secretion of parathyroid hormone. Therefore, vitamin D deficiency may cause rickets, osteopenia, and osteoporosis. It is also reported that vitamin D deficiency has been associated with increased risk of many diseases including cancers, autoimmune diseases, hypertension, and infectious diseases ${ }^{1)}$.

Vitamin D deficiency in the general population is relatively common. In 2008, Gordon et al. ${ }^{2)}$ reported that the prevalence of vitamin D deficiency $(\leq 20 \mathrm{ng} / \mathrm{mL})$ was $12.1 \%$ among healthy infants and toddlers. In 2009, Saintonge et al. ${ }^{3)}$ documented that $14 \%$ of healthy adolescents aged from 12 to 19 years in the United States suffer from vitamin D deficiency. Recent data
Address for correspondence: Jeesuk Yu, MD, PhD

Department of Pediatrics, Dankook University Hospital, Dankook University College of Medicine, 201 Manghyang-ro, Dongnam-gu, Cheonan 31116, Korea

Tel: +82-41-550-6590

Fax: +82-41-559-7940

E-mail: dryujs@dankook.ac.kr 
from the Korean healthy adolescents aged from 10 to 18 years reported that overall $68.1 \%$ had poor vitamin D status with their serum 25-hydroxy vitamin D3 (25[OH]D) level marking lower than $20 \mathrm{ng} / \mathrm{mL}^{4)}$. Recently reported prevalence of vitamin D deficiency in Korean children with epilepsy on anticonvulsants was $61.5 \%{ }^{5)}$, which is comparable to the Swiss study which reported $55 \%$ prevalence of vitamin D deficiency in children on anticonvulsants ${ }^{6}$. The major cause of vitamin D deficiency may be insufficient exposure to sunlight. Obesity and antiepileptic drugs are also considered to be associated with vitamin D deficiency ${ }^{7-9)}$. Hahn et el. ${ }^{10)}$ reported that chronic anticonvulsant therapy resulted in accelerated conversion of vitamin D and its active metabolite, 25-hydroxycholecalciferol, to inactive metabolites by inducing liver microsomal enzymes. Pascussi et el. ${ }^{11)}$ reported that phenobarbital led to the upregulation of 25-hydroxyvitamin D3-24-hydroxylase (CYP24) gene expression through the activation of the nuclear receptor pregnane $\mathrm{X}$ receptor. CYP24 is a mitochondrial enzyme responsible for inactivating vitamin D metabolites. Therefore, children on antiepileptic drugs are more likely to develop vitamin D defi(iency ${ }^{8)}$.

In this study, we evaluated vitamin D status in children with epilepsy who are taking anticonvulsants to determine the prevalence and risk factors of vitamin D deficiency at initial and during follow-up.

\section{Materials and methods}

This study was designed as both a cross-sectional and a retrospective cohort study. A total of 198 children diagnosed with epilepsy at the Department of Pediatrics in Dankook University Hospital, Cheonan, Korea was included. The residence of study subjects was 36.46 to 36.96 degrees North Latitude. Clinical and laboratory data were retrospectively reviewed based on medical records. Vitamin D status of all patients was evaluated by the serum level of $25(\mathrm{OH}) \mathrm{D}$ using chemiluminescent microparticle immunoassay (Abbott Laboratories, Barcelona, Spain). Vitamin D deficiency was defined as serum 25(OH)D levels below $20 \mathrm{ng} / \mathrm{mL}$, according to the cutoff value based on the Endocrine Society Clinical Practice Guideline $2011^{12)}$.

All of the study subjects were not given with vitamin D supplement at the time of the initial assay, and those who were diagnosed with vitamin D deficiency were supplemented with vitamin D and were excluded from further analysis of the study. Study subjects were categorized into 2 groups according to the initial vitamin D levels: vitamin D deficiency and nondeficiency groups. Patients in the nondeficiency group were then followed and subdivided based on the resultant vitamin D level during follow-up: deficiency and nondeficiency groups. Sex, gestational age, birth weight, age at the time of assay, season at the time of assay, height and weight and body mass index (BMI) $z$-scores, duration of anticonvulsants at the time of assay, number and type of anticonvulsants, findings on brain magnetic resonance imaging (MRI), underlying diseases, ambulation ability, and blood chemistry were analyzed.

Abnormal MRI findings included periventricular leukomalacia, brain atrophy, porencephaly, tuberous sclerosis, the agyriapachygyria complex, hydrocephalus, encephalomalacia, corpus callosum agenesis, Mitochondrial encephalomyopathy, lactic acidosis, and stroke-like episodes syndrome, and calcifications. Height and weight and BMI $z$-scores were derived from LMS (Box-cox power, Median, Coefficient of variation) values presented by 2007 Korean Growth Normogram.

\section{Statistical analysis}

Statistical analyses were performed using IBM SPSS Statistics ver. 20.0 (IBM Co., Armonk, NY, USA). Mann-Whitney $U$ test and chi-square test were used to compare continuous and categorical variables between groups, respectively. A paired $t$-test was used to evaluate changes between two time points (values at the recent follow-up subtracted from values at the time of initial assay) to compare the initial serum $25(\mathrm{OH}) \mathrm{D}$ level with that at the last follow-up. Both univariate and multivariate logistic regression were used to evaluate the risk factors of vitamin D deficiency. Pearson correlation analysis was used to evaluate the relationship between the change in serum $25(\mathrm{OH})$ $\mathrm{D}$ levels and the duration of medication or duration of followup. Kaplan-Meier survival analysis was used to investigate the change in vitamin D status from nondeficient to deficient status during follow-up. A $P$-value of less than 0.05 was considered statistically significant.

\section{Ethics statement}

The study was approved by the Institutional Review Board of Dankook University Hospital (IRB No.: 2015-08-010).

\section{Results}

\section{Demographics and characteristics of the study populations at the time of initial assay}

One hundred ninety-eight patients were included in the study. Among them, 102 were males and 96 were females. Eighteen out of 136 patients were premature, and 29 out of 173 patients were low birth weight infants (Table 1). Underlying conditions in all patients were checked. There were 18 patients with mental retardation, 20 patients with cerebral palsy, and 21 patients with mental retardation and cerebral palsy. Among all of the patients, 33 were incapable of ambulation. Seasons at the time of assay were also taken into consideration. Forty-eight cases were evaluated in the spring season, and 61 cases, 24 cases, and 65 cases were evaluated in the summer, fall, and winter seasons, respectively.

The mean age of all subjects at the time of initial assay was $11.45 \pm 4.44$ years, and 95 patients $(48 \%)$ were more than 12 years old. Mean duration of medication at the time of initial assay was 
$3.95 \pm 3.56$ years. Mean serum calcium, phosphorus, and alkaline phosphatase were $9.42 \pm 0.42 \mathrm{mg} / \mathrm{dL}, 4.63 \pm 0.79 \mathrm{mg} / \mathrm{dL}$, and $214.94 \pm 149.37 \mathrm{IU} / \mathrm{L}$, respectively. Mean serum $25(\mathrm{OH}) \mathrm{D}$ level at the time of initial assay was $21.99 \pm 22.12 \mathrm{ng} / \mathrm{mL}$ (Table 1). Mean BMI $z$-score of all patients was $-0.0926 \pm 1.21,24$ patients $(12.1 \%)$ were overweight, and 8 patients (4\%) were obese. Among the total study subjects, 143 patients were on monotherapy $(72.2 \%)$.
Valproate (84 subjects, $42.4 \%$ ) was the most commonly used anticonvulsant followed by oxcarbazepine (55 subjects, 27.8\%) and lamotrigine (48 subjects, 24.2\%). Among the 184 patients evaluated with brain MRI, 51 patients (27.7\%) showed abnormal findings (Table 1).

Table 1. Clinical and laboratory characteristics of the study subjects at initial assay and comparison according to the initial vitamin D status

\begin{tabular}{|c|c|c|c|c|}
\hline Variable & Total subjects & Group without vitamin D deficiency & Group with vitamin D deficiency & $P$-value \\
\hline Total & 198 & $74(37.4)$ & $124(62.6)$ & \\
\hline \multicolumn{5}{|l|}{ Sex } \\
\hline Male & $102(51.5)$ & $34(45.9)$ & $68(54.8)$ & 0.226 \\
\hline Female & $96(48.5)$ & $40(54.1)$ & $56(45.2)$ & \\
\hline \multicolumn{5}{|l|}{ Gestational age $(n=136)$} \\
\hline Term infant & $118(86.8)$ & $46(85.2)$ & $72(87.8)$ & 0.659 \\
\hline Preterm infant & $18(13.2)$ & $8(14.8)$ & $10(12.2)$ & \\
\hline \multicolumn{5}{|l|}{ Birth weight (g) $(n=173)$} \\
\hline$\geq 2,500$ & $144(83.2)$ & $56(83.6)$ & $88(83.0)$ & 0.923 \\
\hline$<2,500$ & $29(16.8)$ & $11(16.4)$ & $18(17.0)$ & \\
\hline \multicolumn{5}{|l|}{ Season at the time of assay } \\
\hline Summer to Fall & 85 (42.9) & $46(62.2)$ & $39(31.5)$ & $<0.001^{*}$ \\
\hline Winter to Spring & $113(57.1)$ & $28(37.8)$ & $85(68.5)$ & \\
\hline Age at the time of initial assay (yr) & $11.45 \pm 4.44$ & $10.41 \pm 4.09$ & $12.07 \pm 4.54$ & $0.007^{*}$ \\
\hline $0-12$ & $103(52.0)$ & $49(66.2)$ & $54(43.5)$ & $0.002^{*}$ \\
\hline$>12$ & $95(48.0)$ & $25(33.8)$ & $70(56.5)$ & \\
\hline Duration of medication (yr) & $3.95 \pm 3.56$ & $3.77 \pm 3.36$ & $4.06 \pm 3.68$ & 0.799 \\
\hline Serum 25(OH)D (ng/mL) & $21.99 \pm 22.12$ & $39.47 \pm 28.13$ & $11.56 \pm 4.55$ & $<0.001^{*}$ \\
\hline Serum calcium (mg/dL) & $9.42 \pm 0.42$ & $9.54 \pm 0.44$ & $9.36 \pm 0.39$ & $0.005^{*}$ \\
\hline Serum P (mg/dL) & $4.63 \pm 0.79$ & $4.74 \pm 0.72$ & $4.57 \pm 0.83$ & 0.431 \\
\hline Serum ALP (IU/L) & $214.94 \pm 149.37$ & $207.26 \pm 89.59$ & $219.22 \pm 174.36$ & 0.760 \\
\hline$z$-score of height & $-0.3442 \pm 1.53$ & $-0.2969 \pm 1.6$ & $-0.3734 \pm 1.49$ & 0.799 \\
\hline z-score of weight & $-0.5419 \pm 1.75$ & $-0.4778 \pm 1.58$ & $-0.5822 \pm 1.85$ & 0.769 \\
\hline$z$-score of body mass index & $-0.0926 \pm 1.21$ & $-0.0935 \pm 1.16$ & $-0.0920 \pm 1.25$ & 0.810 \\
\hline \multicolumn{5}{|l|}{ Brain MRI $(n=184)$} \\
\hline Normal & $133(72.3)$ & $52(78.8)$ & $81(68.6)$ & 0.140 \\
\hline Abnormal & $51(27.7)$ & $14(21.2)$ & $37(31.4)$ & \\
\hline \multicolumn{5}{|l|}{ Underlying condition } \\
\hline Normal & $139(70.2)$ & $53(71.6)$ & $86(69.4)$ & 0.736 \\
\hline Abnormal $^{\text {a) }}$ & $59(29.8)$ & $21(28.4)$ & $38(30.6)$ & \\
\hline \multicolumn{5}{|l|}{ Ambulation } \\
\hline Ambulatory & $165(83.3)$ & $64(86.5)$ & $101(81.5)$ & 0.358 \\
\hline Nonambulatory & $33(16.7)$ & $10(13.5)$ & $23(18.5)$ & \\
\hline Number of medications & $1.41 \pm 0.77$ & $1.36 \pm 0.65$ & $1.44 \pm 0.84$ & 0.943 \\
\hline \multicolumn{5}{|l|}{ Medication type-1 } \\
\hline Monotherapy & $143(72.2)$ & $53(71.6)$ & $90(72.6)$ & 0.884 \\
\hline Polytherapy & $55(27.8)$ & $21(28.4)$ & $34(27.4)$ & \\
\hline \multicolumn{5}{|l|}{ Medication type-2 } \\
\hline NEIAED & $171(86.4)$ & 68 (91.9) & $103(83.1)$ & 0.090 \\
\hline EIAED $^{b)}$ & 27 (13.6) & $6(8.1)$ & $21(16.9)$ & \\
\hline
\end{tabular}

Values are presented as number (\%) or mean \pm standard deviation.

25(OH)D, 25-hydroxy vitamin D; P, phosphorus; ALP, alkaline phosphatase; MRI, magnetic resonance imaging; NEIAED, nonenzyme inducing antiepileptic drug; EIAED, enzyme inducing antiepileptic drug.

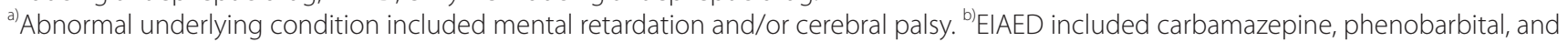
phenytoin. ${ }^{*} P<0.05$. 


\section{Comparison between the group with vitamin $D$ deficiency and the group without vitamin D deficiency at the time of initial assay}

Study subjects were divided according to the vitamin D status at the time of initial assay, and clinical characteristics as well as laboratory results were compared. One hundred twentyfour patients $(62.6 \%)$ were categorized into the group with vitamin D deficiency, consisting of 68 males and 56 females. Vitamin D deficiency was more common in the winter to spring season $(P<0.001)$, and mean age at the time of initial assay was significantly higher in the group with vitamin $D$ deficiency $(12.07 \pm 4.54$ years vs. $10.41 \pm 4.09$ years, $P=0.007)$ (Table 1). Vitamin D deficiency was more frequently observed in the patients aged more than 12 years ( $73 \%$ vs. $27 \%, P=0.002$ ). Patients with vitamin D deficiency showed a lower calcium level $(9.36 \pm 0.39 \mathrm{mg} / \mathrm{dL}$ vs. $9.54 \pm 0.44 \mathrm{mg} / \mathrm{dL}, P=0.005)$, although there was no significant correlation between calcium level and vitamin D level $(r=0.106, P>0.05)$. By multivariate analysis, we found two risk factors associated with vitamin D deficiency; winter to spring season compared to summer to fall season (odds ratio [OR], 3.56; 95\% confidence interval [CI], 1.739-7.387) and

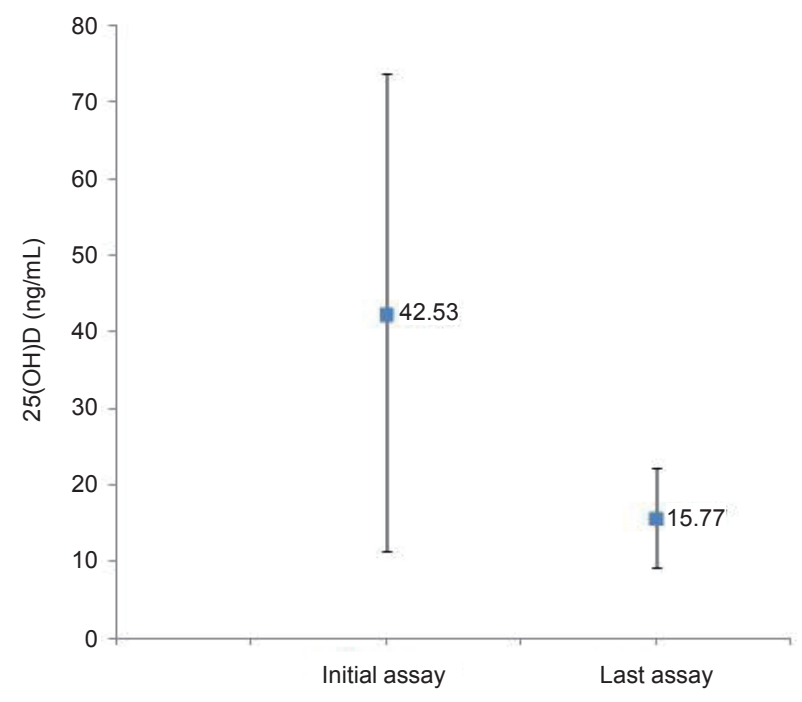

Fig. 1. The mean serum $25(\mathrm{OH}) \mathrm{D}$ level in patients of the non-deficiency group at the time of initial assay and last assay $(P<0.001) .25(\mathrm{OH}) \mathrm{D}, 25$-hydroxy vitamin D3. age more than 12 years (OR, 3.36; 95\% CI, 1.556-7.240) (Table 2).

There were no statistically significant differences in gender, gestational age, birth weight, underlying conditions, ambulation ability, mean duration of medication, mean serum phosphorus and alkaline phosphatase levels, height and weight and BMI $z$-scores, medication type (monotherapy vs. polytherapy; nonenzyme inducing AED vs. enzyme inducing AED), mean number of medications, and findings on brain MRI between the group with vitamin D deficiency and the group without vitamin D deficiency.

\section{Change in vitamin D status during follow-up in patients without vitamin $\mathrm{D}$ deficiency at the time of initial assay}

There were 74 patients who did not have vitamin D deficiency at the time of initial assay. Among them, 17 patients were lost to follow up. The initial mean 25(OH)D level in 57 patients $(77 \%)$, was $42.53 \pm 31.15 \mathrm{ng} / \mathrm{mL}$, but it decreased to $15.77 \pm 6.48 \mathrm{ng} / \mathrm{mL}$. There was a significant decline in the serum $25(\mathrm{OH}) \mathrm{D}$ level during follow up $(-26.76 \pm 33.88, P<0.001)$ (Fig. 1).

During follow-up, only 10 patients $(17.5 \%)$ did not have vitamin D deficiency and 47 subjects (82.5\%) became vitamin $\mathrm{D}$ deficient at the last assay. At 2 years of follow-up, $54.4 \%$ of

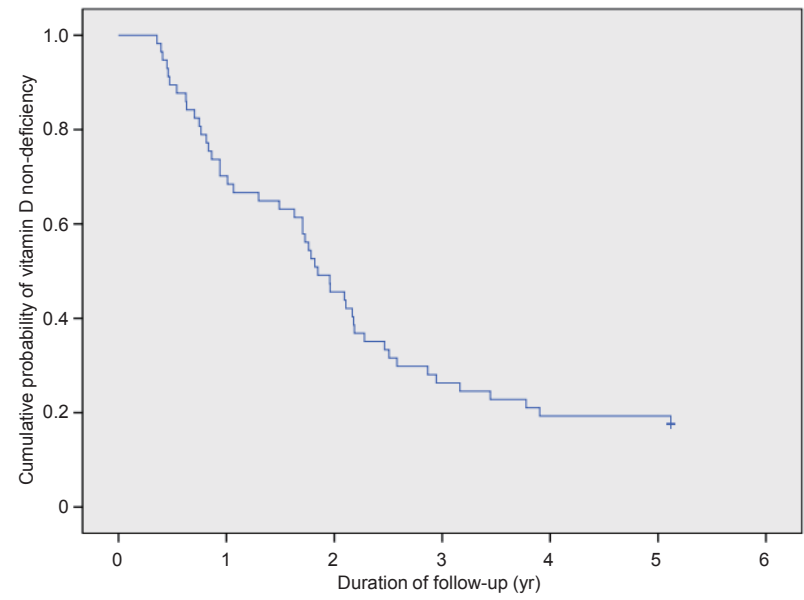

Fig. 2. Vitamin D status from nondeficiency to deficiency during follow-up.

Table 2. Risk factors in children with vitamin D deficiency compared to children without vitamin D deficiency

\begin{tabular}{|c|c|c|c|c|c|c|}
\hline \multirow{2}{*}{ Factor } & \multicolumn{3}{|c|}{ Univariate model } & \multicolumn{3}{|c|}{ Multivariate model } \\
\hline & OR & $95 \% \mathrm{Cl}$ & $P$-value & OR & $95 \% \mathrm{Cl}$ & $P$-value \\
\hline Season at the time of initial assay ${ }^{\text {a) }}$ & 3.58 & $1.958-6.548$ & $<0.001^{*}$ & 3.56 & $1.739-7.387$ & $0.001^{*}$ \\
\hline Age at the time of initial assay ${ }^{b)}$ & 2.54 & $1.397-4.622$ & $0.002^{*}$ & 3.36 & $1.556-7.240$ & $0.002^{*}$ \\
\hline Duration of medication (yr) & 1.13 & $0.768-1.663$ & 0.534 & 0.99 & $0.870-1.122$ & 0.854 \\
\hline Abnormal underlying condition ${ }^{c}$ & 1.12 & $0.592-2.101$ & 0.736 & 0.64 & $0.200-2.029$ & 0.445 \\
\hline Nonambulation & 1.46 & $0.651-3.262$ & 0.360 & 2.36 & $0.471-11.851$ & 0.296 \\
\hline$z$-score of body mass index & 1.001 & $0.767-1.306$ & 0.994 & 1.03 & $0.759-1.408$ & 0.834 \\
\hline
\end{tabular}

$\mathrm{OR}$, odds ratio; $\mathrm{Cl}$, confidence interval.

a) Winter to spring vs. summer to fall. ${ }^{\text {b) }}$ More than 12 years vs. less than 12 years. ${ }^{c}$ Abnormal underlying condition included mental retardation and/or cerebral palsy. ${ }^{*} P<0.05$. 


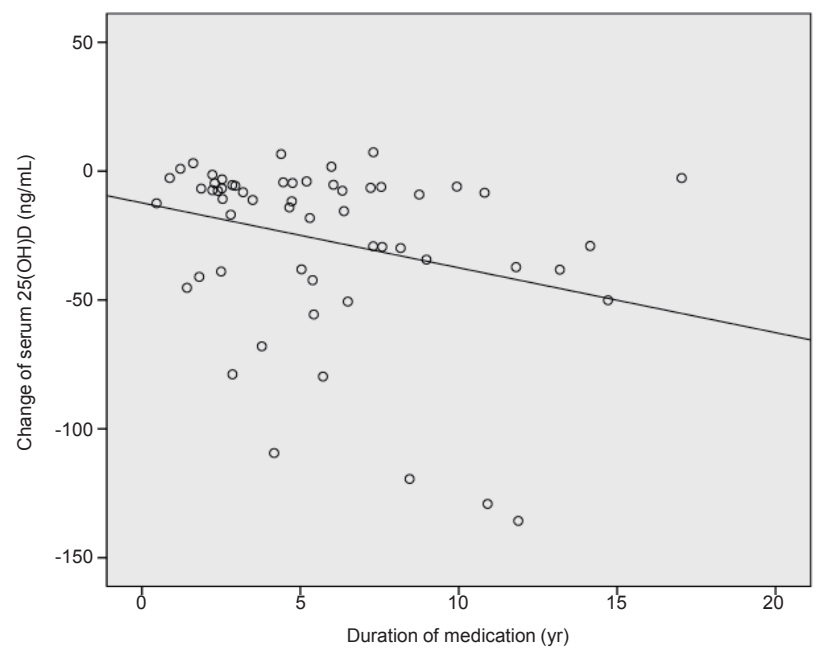

Fig. 3. Correlation between the change of serum 25(OH)D levels during followup and the duration of medication $(r=-0.283, P=0.033)$. 25(OH)D, 25-hydroxy vitamin D3.

patients became vitamin D deficient and at 3 years, $73.7 \%$ of patients became deficient (Fig. 2). According to the analysis based on the total medication duration, one-third of the study subjects $(\mathrm{n}=19,33.3 \%)$ became vitamin $\mathrm{D}$ deficient after 3 years of medication, 28 patients $(49.1 \%)$ after 5 years of medication, and 39 patients $(68.4 \%)$ by 7 years of medication.

The change of serum 25(OH)D levels during follow-up demonstrated a weak negative correlation with the duration of medication $(r=-0.283, P=0.033)$ (Fig. 3). There was a positive correlation between serum $25(\mathrm{OH}) \mathrm{D}$ levels and serum phosphorus levels at the time of last assay $(r=0.356, P=0.016)$ (Fig. 4).

There were no statistically significant differences in gender, gestational age, birth weight, underlying conditions, ambulation ability, mean serum calcium and phosphorus level, alkaline phosphatase level, height and weight and BMI $z$-scores, medication type, mean number of medication, and findings on brain MRI between the group with vitamin D deficiency and the group without vitamin D deficiency during follow-up.

\section{Comparison between the two groups subdivided according to the substantial changes in serum 25(OH)D level during follow-up}

The patients who were followed up were subdivided into two groups according to the presence of substantial decrease in vitamin D level. Substantial decrease in vitamin D level was defined as a decline of more than $15 \mathrm{ng} / \mathrm{mL}$ in the serum $25(\mathrm{OH}) \mathrm{D}$ level from the initial assay to the last assay. Thirty-two patients $(56 \%)$ did not show a significant decline in vitamin D level and were classified into group A, and 25 patients (44\%) who showed a significant decline were classified into group B (Table $3)$. The mean change of serum $25(\mathrm{OH}) \mathrm{D}$ level was $-5.17 \pm 5.03$ $\mathrm{ng} / \mathrm{mL}$ in group $\mathrm{A}$ compared to $-54.4 \pm 35.06 \mathrm{ng} / \mathrm{mL}$ in group $\mathrm{B}(P<0.001)$. Mean duration of medication $(7.05 \pm 3.89$ years

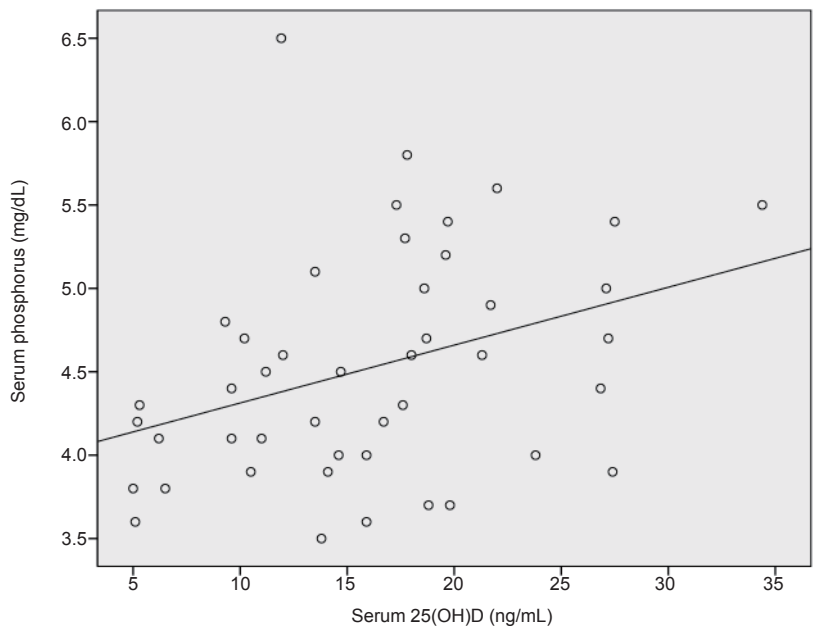

Fig. 4. Correlation between serum $25(\mathrm{OH}) \mathrm{D}$ levels and serum phosphorus levels at the time of last assay $(r=0.356, P=0.016)$. 25(OH)D, 25-hydroxy vitamin D3.

vs. $4.7 \pm 3.46$ years, $P=0.012$ ) and mean number of medications ( $1.84 \pm 1.07$ vs. $1.28 \pm 0.46, P=0.037)$ were significantly higher in group B. Mean serum phosphorus $(4.29 \pm 0.61 \mathrm{mg} / \mathrm{dL}$ vs. $4.71 \pm 0.69 \mathrm{mg} / \mathrm{dL}, P=0.022)$ and alkaline phosphatase (160.52 $\pm 76.83 \mathrm{IU} / \mathrm{L}$ vs. $247.4 \pm 139.03 \mathrm{IU} / \mathrm{L}, P=0.028)$ levels were significantly lower in group $\mathrm{B}$, and there was a more significant decrease in serum phosphorus level $(-0.51 \pm 0.54 \mathrm{mg} / \mathrm{dL}$ vs. $0.05 \pm 0.73 \mathrm{mg} / \mathrm{dL}, P=0.013$ ) in group B. Brain MRI abnormality, abnormal underlying conditions, and nonambulatory status were more frequently present in group $\mathrm{B}(P<0.05)$ (Table 3$)$.

There were no statistically significant differences in gender, gestational age, birth weight, season at the time of last assay, age at the time of last assay, mean serum calcium, height and weight and BMI $z$-scores, and medication type (monotherapy vs. polytherapy; nonenzyme inducing AED vs. enzyme inducing AED) between groups A and B.

In the univariate model, factors associated with an increased risk of substantial decrease in vitamin D level were mean duration of medication, abnormal brain MRI findings, abnormal underlying conditions, nonambulatory status, and mean number of medications, although none of them were statistically significant risk factors associated with a substantial decrease in vitamin D level in the multivariate model (Table 4).

\section{Discussion}

This study showed a high prevalence of vitamin D deficiency (62.6\%; 124 out of the 198 patients) in a pediatric epilepsy population on antiepileptic drugs. Two previous studies showed a prevalence of vitamin D deficiency in a pediatric epilepsy population of about $22 \%{ }^{13)}$ and $25 \%$, respectively ${ }^{14)}$. The reason why the previous two studies showed different prevalence compared to this study might be attributable to the difference in target ethnic group, environmental difference such as the amount of sunshine, and the number of patients included in 
Table 3. Clinical and laboratory data of the 57 subjects without vitamin D deficiency at the initial assay subdivided based on the presence of a substantial decrease in the serum $25(\mathrm{OH}) \mathrm{D}$ level during follow-up

\begin{tabular}{|c|c|c|c|}
\hline Factor & Group A $(\triangle 25(\mathrm{OH}) \mathrm{D}<15 \mathrm{ng} / \mathrm{mL})$ & Group B $(\triangle 25(\mathrm{OH}) \mathrm{D} \geq 15 \mathrm{ng} / \mathrm{mL})$ & $P$-value \\
\hline Total & $32(56.1)$ & $25(43.9)$ & \\
\hline Duration of follow-up (yr) & $1.66 \pm 1.06$ & $1.79 \pm 1.07$ & 0.505 \\
\hline \multicolumn{4}{|l|}{ Sex } \\
\hline Male & $14(43.8)$ & $10(40.0)$ & 0.776 \\
\hline Female & $18(56.2)$ & $15(60.0)$ & \\
\hline \multicolumn{4}{|l|}{ Gestational age $(n=41)$} \\
\hline Term infant & $22(88.0)$ & $11(68.8)$ & 0.129 \\
\hline Preterm infant & $3(12.0)$ & $5(31.2)$ & \\
\hline \multicolumn{4}{|l|}{ Birth weight $(g)(n=52)$} \\
\hline$\geq 2,500$ & $25(86.2)$ & $16(69.6)$ & 0.144 \\
\hline$<2,500$ & $4(13.8)$ & $7(30.4)$ & \\
\hline \multicolumn{4}{|l|}{ Season at the time of last assay } \\
\hline Summer to Fall & $14(43.8)$ & $7(28.0)$ & 0.221 \\
\hline Winter to Spring & $18(56.2)$ & $18(72.0)$ & \\
\hline Age at the time of last assay (yr) & $11.47 \pm 3.82$ & $12.67 \pm 3.92$ & 0.094 \\
\hline $0-12$ & $21(65.6)$ & $10(40.0)$ & 0.054 \\
\hline$>12$ & $11(34.4)$ & $15(60.0)$ & \\
\hline Duration of medication at the time of last assay (yr) & $4.70 \pm 3.46$ & $7.05 \pm 3.89$ & $0.012^{*}$ \\
\hline Serum 25(OH)D (ng/mL) & $19.18 \pm 5.24$ & $11.40 \pm 5.19$ & $<0.001^{*}$ \\
\hline Serum calcium (mg/dL) & $9.46 \pm 0.31$ & $9.24 \pm 0.12$ & 0.159 \\
\hline Serum $P(\mathrm{mg} / \mathrm{dL})$ & $4.71 \pm 0.69$ & $4.29 \pm 0.61$ & $0.022^{*}$ \\
\hline Serum ALP (IU/L) & $247.4 \pm 139.03$ & $160.52 \pm 76.83$ & $0.028^{*}$ \\
\hline Change of serum calcium (mg/dL) & $-0.08 \pm 0.53$ & $-0.29 \pm 0.53$ & 0.346 \\
\hline Change of serum $P(\mathrm{mg} / \mathrm{dL})$ & $0.05 \pm 0.73$ & $-0.51 \pm 0.54$ & $0.013^{*}$ \\
\hline Change of serum ALP (IU/L) & $2.2 \pm 76.35$ & $-29.27 \pm 73.88$ & 0.141 \\
\hline$z$-score of height & $-0.1009 \pm 1.47$ & $-0.6365 \pm 1.45$ & 0.186 \\
\hline$z$-score of weight & $-0.2638 \pm 1.37$ & $-0.6052 \pm 1.68$ & 0.532 \\
\hline$z$-score of body mass index & $-0.1928 \pm 1.06$ & $-0.0365 \pm 1.47$ & 0.371 \\
\hline \multicolumn{4}{|l|}{ Brain MRI $(n=52)$} \\
\hline Normal & $25(86.2)$ & $14(60.9)$ & $0.036^{*}$ \\
\hline Abnormal & $4(13.8)$ & $9(39.1)$ & \\
\hline \multicolumn{4}{|l|}{ Underlying condition } \\
\hline Normal & $26(81.2)$ & $14(56.0)$ & $0.039^{*}$ \\
\hline Abnormala $\left.\right|^{a)}$ & $6(28.8)$ & $11(44.0)$ & \\
\hline \multicolumn{4}{|l|}{ Ambulation } \\
\hline Ambulatory & $31(96.9)$ & $18(72.0)$ & $0.007^{*}$ \\
\hline Nonambulatory & $1(3.1)$ & $7(28.0)$ & \\
\hline No. of medications & $1.28 \pm 0.46$ & $1.84 \pm 1.07$ & $0.037^{*}$ \\
\hline \multicolumn{4}{|l|}{ Medication type-1 } \\
\hline Monotherapy & $23(71.9)$ & $13(52.0)$ & 0.123 \\
\hline Polytherapy & $9(28.1)$ & $12(48.0)$ & \\
\hline \multicolumn{4}{|l|}{ Medication type-2 } \\
\hline NEIAED & $31(96.9)$ & $21(84.0)$ & 0.157 \\
\hline EIAED $^{b)}$ & $1(3.1)$ & $4(16.0)$ & \\
\hline
\end{tabular}

Values are presented as number (\%) or mean \pm standard deviation.

25(OH)D, 25-hydroxy vitamin D; P, phosphorus; ALP, alkaline phosphatase; MRI, magnetic resonance imaging; NEIAED, nonenzyme inducing antiepileptic drug; EIAED, enzyme inducing antiepileptic drug.

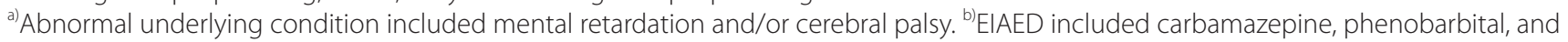
phenytoin. ${ }^{*} P<0.05$.

this study. Higher prevalence of vitamin D deficiency in Korean population compared to that of United States population suggests that the ethnic or environmental differences have significant influence on the prevalence of vitamin D deficiency.

Vitamin D deficiency is defined as a low serum level of $25(\mathrm{OH}) \mathrm{D}$, with insufficient consensus about the cutoff 
Table 4. Risk factors associated with a substantial decrease in the serum 25(OH)D level during follow-up

\begin{tabular}{|c|c|c|c|c|c|c|}
\hline \multirow{2}{*}{ Factor } & \multicolumn{3}{|c|}{ Univariate model } & \multicolumn{3}{|c|}{ Multivariate model } \\
\hline & OR & $95 \% \mathrm{Cl}$ & $P$-value & OR & $95 \% \mathrm{Cl}$ & $P$-value \\
\hline Duration of medication & 1.19 & $1.020-1.399$ & $0.027^{*}$ & 1.079 & $0.887-1.329$ & 0.472 \\
\hline Abnormal brain MRI & 4.02 & $1.044-15.457$ & $0.043^{*}$ & 2.795 & $0.456-17.121$ & 0.266 \\
\hline Abnormal underlying condition & 3.41 & $1.038-11.171$ & $0.043^{*}$ & 0.298 & $0.024-3.715$ & 0.347 \\
\hline Nonambulation & 12.06 & $1.371-106.04$ & $0.025^{*}$ & 4.068 & $0.279-59.231$ & 0.305 \\
\hline No. of medication & 2.71 & $1.182-6.191$ & $0.019^{*}$ & 2.644 & $0.741-9.437$ & 0.134 \\
\hline
\end{tabular}

25(OH)D, 25-hydroxy vitamin D; OR, odds ratio; Cl, confidence interval; MRI, magnetic resonance imaging.

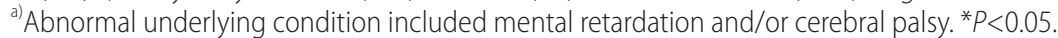

value of 25(OH)D level. Most authors suggest that 25(OH) D concentration $<20 \mathrm{ng} / \mathrm{mL}$ is an indicator of vitamin $\mathrm{D}$ deficiency, and a serum level of $21-29 \mathrm{ng} / \mathrm{mL}$ is considered vitamin D insufficient ${ }^{12,15-17)}$.

In this study, the criterion for vitamin D deficiency was set as a serum level of $25(\mathrm{OH}) \mathrm{D}<20 \mathrm{ng} / \mathrm{mL}$ based on the reference mentioned above.

Several previous studies showed the risk factors for vitamin D deficiency in a pediatric epilepsy population on antiepileptic drugs. In 2008, Nettekoven et al. ${ }^{8}$ reported that the prevalence of vitamin D deficiency in pediatric epilepsy patients on antiepileptic drugs is high, especially in the group receiving polytherapy. A recent study on vitamin D status in adult patients with epilepsy documented that patients taking enzymeinducing antiepileptic drugs (e.g., carbamazepine, phenobarbital, phenytoin, primidone) had a higher prevalence of vitamin $\mathrm{D}$ deficiency compared to the patients who were not taking enzyme-inducing antiepileptic drugs ${ }^{18)}$. Another longitudinal cohort study in children on antiepileptic drugs reported a significant decline in vitamin D level among patients during followup, and showed that longer duration of antiepileptic drugs was associated with a significant decrease in the $25(\mathrm{OH}) \mathrm{D}$ level $\mathrm{l}^{5)}$.

In general, aging was recognized as a risk factor for vitamin $\mathrm{D}$ deficiency ${ }^{1}$. Aging contributes to a decreased concentration of 7-dehydrocholesterol, a precursor of vitamin D3. Obesity is also considered to trigger vitamin D deficiency, of which the lipid solubility results in its deposition in body fat compartments ${ }^{7}$.

Our study showed significant differences in season at the time of assay, age, serum calcium concentration between the vitamin $\mathrm{D}$ deficiency group and vitamin D nondeficiency group. Polytherapy, enzyme inducing antiepileptic drugs and medication duration did not show any significant difference, which might be attributed to the small number of patients included in this study.

The major difference in this study from other studies is that we simultaneously performed a cross-sectional study as well as a cohort study. In this study, most of the patients had vitamin D deficiency during follow-up. Several factors including mean duration of medication, abnormal findings on brain MRI, abnormal underlying conditions, nonambulation, and mean number of medications had a significant influence on substantial change in the serum $25(\mathrm{OH}) \mathrm{D}$ level. However, none of the factors was confirmed as a risk factor for vitamin $\mathrm{D}$ deficiency or for substantial change in serum $25(\mathrm{OH}) \mathrm{D}$ levels in the multivariate model. This might be due to the small number of patients included in the study and relatively short follow-up duration.

Vitamin D deficiency influences the musculoskeletal system, therefore it especially causes growth retardation and rickets in children ${ }^{1,19)}$. Muscle weakness is also related to vitamin D deficiency ${ }^{20,21)}$. Vitamin $\mathrm{D}$ also affects various systems other than the musculoskeletal system. Vitamin D deficiency is thought to be associated with cancer ${ }^{22-25)}$, diabetes mellitus ${ }^{26-28)}$, multiple sclerosis $^{26)}$, rheumatoid arthritis ${ }^{26)}$, hypertension ${ }^{29)}$, various respiratory diseases such as asthma ${ }^{30)}$, pneumonia ${ }^{31)}$, upper respiratory tract infection ${ }^{32)}$, and psychiatric diseases such as depression ${ }^{33)}$.

This study shows that vitamin D deficiency is common in children with epilepsy, especially in adolescents more than 12 years of age. Moreover, this study emphasizes the importance of monitoring the vitamin $\mathrm{D}$ level regularly because most of the pediatric epilepsy patients who showed normal serum vitamin $\mathrm{D}$ level at the time of the first assay became vitamin $\mathrm{D}$ deficient during follow-up, especially in the presence of longer medication duration, brain MRI abnormality, abnormal underlying conditions, and nonambulatory status.

\section{Conflict of interest}

No potential conflict of interest relevant to this article was reported.

\section{Acknowledgments}

The present research was conducted by the research fund of Dankook University in 2014.

\section{References}

1. Holick MF, Chen TC. Vitamin D deficiency: a worldwide problem with health consequences. Am J Clin Nutr 2008;87:1080S-6S.

2. Gordon CM, Feldman HA, Sinclair L, Williams AL, Kleinman PK, Perez-Rossello J, et al. Prevalence of vitamin D deficiency among healthy infants and toddlers. Arch Pediatr Adolesc Med 2008;162:505-12.

3. Saintonge S, Bang H, Gerber LM. Implications of a new 
definition of vitamin $\mathrm{D}$ deficiency in a multiracial us adolescent population: the National Health and Nutrition Examination Survey III. Pediatrics 2009;123:797-803.

4. Kim SH, Oh MK, Namgung R, Park MJ. Prevalence of 25-hydroxyvitamin D deficiency in Korean adolescents: association with age, season and parental vitamin D status. Public Health Nutr 2014;17:122-30.

5. Lee YJ, Park KM, Kim YM, Yeon GM, Nam SO. Longitudinal change of vitamin D status in children with epilepsy on antiepileptic drugs: prevalence and risk factors. Pediatr Neurol 2015;52:153-9.

6. Ramelli V, Ramelli GP, Lava SA, Siegenthaler GM, Cantù $\mathrm{M}$, Bianchetti MG, et al. Vitamin D status among children and adolescents on anticonvulsant drugs in southern Switzerland. Swiss Med Wkly 2014;144:w13996.

7. Wortsman J, Matsuoka LY, Chen TC, Lu Z, Holick MF. Decreased bioavailability of vitamin D in obesity. Am J Clin Nutr 2000;72:690-3.

8. Nettekoven S, Strohle A, Trunz B, Wolters M, Hoffmann S, Horn R, et al. Effects of antiepileptic drug therapy on vitamin $\mathrm{D}$ status and biochemical markers of bone turnover in children with epilepsy. Eur J Pediatr 2008;167:1369-77.

9. Sonmez FM, Donmez A, Namuslu M, Canbal M, Orun E. Vitamin D deficiency in children with newly diagnosed idiopathic epilepsy. J Child Neurol 2015;30:1428-32.

10. Hahn TJ, Birge SJ, Scharp CR, Avioli LV. Phenobarbitalinduced alterations in vitamin D metabolism. J Clin Invest 1972;51:741-8.

11. Pascussi JM, Robert A, Nguyen M, Walrant-Debray O, Garabedian M, Martin P, et al. Possible involvement of pregnane X receptor-enhanced CYP24 expression in druginduced osteomalacia. J Clin Invest 2005;115:177-86.

12. Holick MF, Binkley NC, Bischoff-Ferrari HA, Gordon CM, Hanley DA, Heaney RP, et al. Evaluation, treatment, and prevention of vitamin D deficiency: an Endocrine Society clinical practice guideline. J Clin Endocrinol Metab 2011;96:1911-30.

13. Fong CY, Riney CJ. Vitamin D deficiency among children with epilepsy in South Queensland. J Child Neurol 2014; 29:368-73

14. Shellhaas RA, Barks AK, Joshi SM. Prevalence and risk factors for vitamin D insufficiency among children with epilepsy. Pediatr Neurol 2010;42:422-6.

15. Chapuy MC, Preziosi P, Maamer M, Arnaud S, Galan P, Hercberg S, et al. Prevalence of vitamin D insufficiency in an adult normal population. Osteoporos Int 1997;7:439-43.

16. Heaney RP, Dowell MS, Hale CA, Bendich A. Calcium absorption varies within the reference range for serum 25-hydroxyvitamin D. J Am Coll Nutr 2003;22:142-6.

17. Holick MF, Siris ES, Binkley N, Beard MK, Khan A, Katzer JT, et al. Prevalence of Vitamin D inadequacy among postmenopausal North American women receiving osteoporosis therapy. J Clin Endocrinol Metab 2005;90:3215-24
18. Teagarden DL, Meador KJ, Loring DW. Low vitamin D levels are common in patients with epilepsy. Epilepsy Res 2014;108:1352-6.

19. Shin YH, Shin HJ, Lee YJ. Vitamin D status and childhood health. Korean J Pediatr 2013;56:417-23.

20. Simpson RU, Thomas GA, Arnold AJ. Identification of 1,25-dihydroxyvitamin D3 receptors and activities in muscle. J Biol Chem 1985;260:8882-91.

21. Visser M, Deeg DJ, Lips P; Longitudinal Aging Study Amsterdam. Low vitamin D and high parathyroid hormone levels as determinants of loss of muscle strength and muscle mass (sarcopenia): the Longitudinal Aging Study Amsterdam. J Clin Endocrinol Metab 2003;88:5766-72.

22. Hanchette CL, Schwartz GG. Geographic patterns of prostate cancer mortality. Evidence for a protective effect of ultraviolet radiation. Cancer 1992;70:2861-9.

23. Grant WB. An estimate of premature cancer mortality in the U.S. due to inadequate doses of solar ultraviolet-B radiation. Cancer 2002;94:1867-75.

24. Gorham ED, Garland CF, Garland FC, Grant WB, Mohr SB, Lipkin M, et al. Vitamin D and prevention of colorectal cancer. J Steroid Biochem Mol Biol 2005;97:179-94.

25. Giovannucci E. Epidemiology of vitamin D and colorectal cancer: casual or causal link? J Steroid Biochem Mol Biol 2010;121:349-54.

26. Ponsonby AL, McMichael A, van der Mei I. Ultraviolet radiation and autoimmune disease: insights from epidemiological research. Toxicology 2002;181-182:71-8.

27. Mohammadian S, Fatahi N, Zaeri H, Vakili MA. Effect of vitamin $\mathrm{d} 3$ supplement in glycemic control of pediatrics with type 1 diabetes mellitus and vitamin d deficiency. J Clin Diagn Res 2015;9:SC05-7.

28. Reddy GB, Sivaprasad M, Shalini T, Satyanarayana A, Seshacharyulu M, Balakrishna N, et al. Plasma vitamin D status in patients with type 2 diabetes with and without retinopathy. Nutrition 2015;31:959-63.

29. Kao KT, Abidi N, Ranasinha S, Brown J, Rodda C, McCallum $\mathrm{Z}$, et al. Low vitamin $\mathrm{D}$ is associated with hypertension in paediatric obesity. J Paediatr Child Health 2015;51:120713.

30. Gupta A, Bush A, Hawrylowicz C, Saglani S. Vitamin D and asthma in children. Paediatr Respir Rev 2012;13:236-43.

31. Quraishi SA, Bittner EA, Christopher KB, Camargo CA Jr. Vitamin D status and community-acquired pneumonia: results from the third National Health and Nutrition Examination Survey. PLoS One 2013;8:e81120.

32. Ginde AA, Mansbach JM, Camargo CA Jr. Association between serum 25-hydroxyvitamin D level and upper respiratory tract infection in the Third National Health and Nutrition Examination Survey. Arch Intern Med 2009;169:384-90.

33. Gloth FM 3rd, Alam W, Hollis B. Vitamin D vs broad spectrum phototherapy in the treatment of seasonal affective disorder. J Nutr Health Aging 1999;3:5-7. 